\title{
Fillers for Solid-State Polymer Electrolytes: Highlight
}

\author{
Srun Jung, Dae Won Kim, Sang Deuk Lee," Minserk Cheong, Dinh Quan Nguyen, \\ Byung Won Cho, ${ }^{\dagger *}$ and Hoon Sik Kim
}

\author{
Department of Chemistry and Research Institute of Basic Sciences, Kunt Hee Lniversity, Seoul 130-701, Kored \\ "E-mail: khs200tiakhu.ackr \\ ${ }^{\dagger}$ Division of Energv and Enwironment. Korea Institute of Science and Technologv, Seoul 136-791, Korea \\ ${ }^{*}$ E-mail: uniqueokíhamail.net \\ Received July 15, 2009. Accepted September 1, 2009
}

\begin{abstract}
The current solid polymer electroly tes suffer from poor conductivity, low mechanical and electrochemical stability toward the lithium electrodes. To improve the performance of solid polymer electrolytes, the addition of nanoparticle fillers to the polymer electrolyte is being extensively investigated. In this paper, a brief review on the state of art of solid fillers for lithium battery electrolytes is presented.
\end{abstract}

Key Words: Secondary battery, Lithium. Fillers, Nanocomposite, Solid-state electrolyte

\section{Introduction}

A solid state electrolyte (SPE) can be defined as a solid solution of the conducted ions. Ions can be transported inside and through the host under the effect of an electric field by

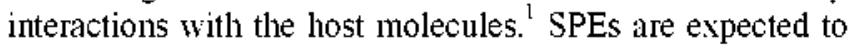
contribute to the realization of lithium battery systems with much improved safety. energy density. and design flexibility. Moreover. the lithium dendrite formation on metal lithium anodes can be prevented mechanically and morphologically if highly stable and highly conducting SPEs are materialized. and thus lithium metal batteries. the most desirable battery system with the highest energy density, can be brought into the market.

Among the SPEs so far reported. PEO-LiX is the most intensively studied electrolyte systems. Unfortunately. most of the SPEs based on PEO-LiX exhibits low ionic conductivities at ambient temperatures $\left(\sigma<10^{\circ} \mathrm{S} \mathrm{cm}^{-1}\right)$ because of their crystallization tendencies. ${ }^{3-5}$ To improve the ionic conductivity of SPEs. a concept of gel poly mer electroly tes (GPE) was introduced. ${ }^{6}$ The conductivity PEO-LiX increased significantly by incorporating a liquid plasticizer into a SPE. but at the sacrifices of mechanical strength and the compatibility of the electrolyte with lithium.

In Table 1 . various types of lithium battery electrolytes are summarized.

Recently, a new strategy to overcome the disadvantages of SPEs is being intensively studied. Instead of liquid plasticizers. nanosized ceramic powders or molecular sieves were dispersed directly into the polymer hosts to gain mechanical strength and to improve ionic conductivities. These innovated electroly'tes are known as composite polymer electrolytes (CPEs). in which the added solid particles. known as fillers, incorporate into the host polymer. ${ }^{8}$ This strategy was more encouraged by $Z$. Gadjourova et al. ${ }^{9}$ who proved that the conductivity in a static and ordered environment of the crystalline phase could be greater than that in the equivalent amorphous material above $T_{q}$. The study also showed that in a crystalline phase. ion transport is dominated by the cations. indicated by $\mathrm{Li}^{-}$transference number in the case of lithium battery polymer electrolytes.

In a conventional SPE. relaxation and segmental motion of the solvent chains are regarded as the key factors in enabling ion transport. suggesting that a sufficient conductivity can be

Table 1. Physical and electrochemical properties of various electrolytes for lithium batteries.

\begin{tabular}{|c|c|c|c|c|}
\hline Property & $\begin{array}{c}\text { Organic carbonate-based } \\
\text { electrolytes }\end{array}$ & $\begin{array}{l}\text { Ionic liquid-based } \\
\text { electrolytes }\end{array}$ & $\begin{array}{l}\text { Solid polymer } \\
\text { electrolytes (SPE) }\end{array}$ & $\begin{array}{l}\text { Polymer gel } \\
\text { electrolytes (GPE) }\end{array}$ \\
\hline mechanics & $\begin{array}{c}\text { low flexibility and } \\
\text { stability }\end{array}$ & $\begin{array}{l}\text { low flexibility and } \\
\text { stability }\end{array}$ & $\begin{array}{l}\text { high flexibility and } \\
\text { stability }\end{array}$ & $\begin{array}{l}\text { moderate flexibility } \\
\text { and stability }\end{array}$ \\
\hline $\begin{array}{l}\text { electrochemical and } \\
\text { chemical stability }\end{array}$ & moderate & either low or moderate & high & moderate \\
\hline thermal stability & low: & high & high & moderate \\
\hline conductivity & high & either high or moderate & very low & moderate \\
\hline $\begin{array}{l}\text { lithium selective } \\
\text { transference }\end{array}$ & high & low & high & high \\
\hline
\end{tabular}


Table 2. Highest ionic conductivity and $\mathrm{Li}^{-}$transference number reported.

\begin{tabular}{|c|c|c|c|c|}
\hline \multirow{2}{*}{\multicolumn{2}{|c|}{$\begin{array}{l}\text { Class of polymer electrolyte } \\
\text { (Polymer-LiX) }\end{array}$}} & \multirow{2}{*}{ Section } & \multicolumn{2}{|c|}{ Highest value reported ${ }^{a}$} \\
\hline & & & Conductivity $\left(\mathrm{S} \mathrm{cm}^{-1}\right)$ & $\mathrm{Li}^{-}$transference number \\
\hline \multirow{2}{*}{\multicolumn{2}{|c|}{$\begin{array}{c}\text { PEO-based SPEs } \\
\text { poly[bis( methoxyethoxyethoxy)phosphazene]-based } \\
\text { SPEs }\end{array}$}} & & $10^{7}$ & \multirow[b]{2}{*}{$0.3^{28}$} \\
\hline & & 2.1 & $1.7 \times 10^{.5}$ & \\
\hline \multirow{9}{*}{$\begin{array}{c}\text { SPEs } \\
\text { containing }\end{array}$} & Inert oxide ceramic & 2.1 & $3.8 \times 10^{4} 3$ & $0.8^{20}$ \\
\hline & Treated $\mathrm{SiO}_{2}$ & 2.2 & $2.3 \times 10^{-5}+3$ & $0.25^{42}$ \\
\hline & Molecular sieves or zeolite & 2.3 & $1.4 \times 10^{550}$ & $0.5^{52}$ \\
\hline & Rare-earth ceramics & 2.4 & $3.8 \times 10^{455}$ & $0.7^{55}$ \\
\hline & Solid super acid & 2.5 & $2.1 \times 10^{-5} \leqslant 1$ & $0.8^{61-62}$ \\
\hline & Ferroelectric material & 2.6 & $2.6 \times 10^{-5} 5 s b$ & $0.4^{6.4 c}$ \\
\hline & Carbon & 2.7 & $2.0 \times 10^{-4630}$ & $\mathrm{n} / \mathrm{r}$ \\
\hline & Cellulose nanocrystals & 3 & $10^{5 \% 9}$ & $0.3^{69}$ \\
\hline & Active fillers & 4 & $3 \times 10^{12}$ & 0.4 \\
\hline \multicolumn{2}{|c|}{ Nanogel composite electrolyte } & 5 & $4.0 \times 10^{3} \mathrm{u}_{11}$ & $0.7^{8: b}$ \\
\hline
\end{tabular}

${ }^{a}$ measured at room temperature. ${ }^{b}$ at $30^{\circ} \mathrm{C}$. ' at $70^{\circ} \mathrm{C}$. nir: not reported.

obtained only when the poly mer is over its amorphous state. ${ }^{10}$ The addition of a filler to a polymer improve was found to improve the ionic conductivity by reducing the crystallization tendency. ${ }^{11.12}$ In addition, Jiang et al. also indicated that the presence of a ceramic filler significantly enhanced cation transference number and interfacial stability between the electrolyte and lithium metal electrode. ${ }^{13.1+}$

In general, inorganic fillers may be classified into two groups: active and passive. The active group consists of materials that participate in the ionic conduction process. while the inactive group consists of materials that do not involve in the lithium transport process. However. in all cases. the particle size and the characteristics of the fillers play vital roles in the electrochemical properties of the electroly'tes.

During the last two years. CPEs have attracted great interest. Achievements made in this period strongly suggest that CPEs are the most promising next generation electrolytes for lithium batteries

In this paper a brief review of fillers for CPEs was presented. For a convenient comparison. the highest conductivity and $\mathrm{Li}^{+}$ transference number for various electrolyte systems were listed in Table 2.

\section{Inactive Inorganic Fillers}

Inert oxide ceramics. As conventional compounds. oxide ceramic fillers including $\mathrm{Al}_{2} \mathrm{O}_{3}{ }^{15}{ }^{15} \mathrm{TiO}_{2}{ }^{16} \mathrm{ZrO}_{2}{ }^{17.18}$ have been of major interest in the study of inorganic fillers for SPEs.

The first study on the fillers for lithium battery polymer electroly tes was carried out with $\mathrm{Al}_{2} \mathrm{O}_{3}{ }^{19}$ According to Croce et $\mathrm{al}$. either $\mathrm{TiO}_{2}$ or $\mathrm{Al}_{2} \mathrm{O}_{3}$ dispersed in $\mathrm{PEO}-\mathrm{LiClO}_{4}(10 \mathrm{wt} \%)$ forms complexes with the basic oxygen atoms in the PEO chains and acts as cross-linking centers for PEO segments. thereby reducing the reorganization tendency of the polymer chain and promoting preferred $\mathrm{Li}^{+}$transport at the boundaries of the filler particles. ${ }^{.1}$ Indeed. below the melting temperature of PEO, the conductivity of PEO-based nanocomposite electroly'tes was reported to be strongly' dependent on the thermal history. ${ }^{21}$ Such functional fillers are called somewhere as "solid plasticizers". 14,22 However. in fact. the role of ceramic fillers seems to be quite different from that of liquid plasticizers, which significantly change the dynamics of polymer chain and thus promote the segmental conductivity ${ }^{23: 4}$ In contrast, the $T_{g}$ values of the PEO-based electrolyte systems were not noticeably changed by the addition of ceramic fillers. preserving the initial amorphous structures. Lewis acid-base type interactions between filler surface groups and cations/ anions appear to be responsible for conductivity enhancement

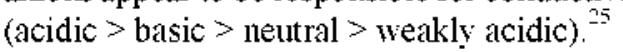

Most of the studies have focused on the synthesis of nanosized fillers because the mechanical strength and the electrochemical performance of the electrolytes are expected to increase with the decreasing size of fillers. In fact. Krawiec $e t$ al. showed that the conductivity of $\mathrm{PEO}-\mathrm{LiBF}_{4}$ sy stem increased with the decreasing size of $\mathrm{Al}_{2} \mathrm{O}_{3}$ filler particle. ${ }^{-6}$ On the contrary. micron-sized titanium oxide consisting of $\mathrm{Ti}_{-} \mathrm{O}_{3}$, $\mathrm{TiO}$, and $\mathrm{TiO}_{2}$ prepared by ball milling was also found to remarkably reduce the interface resistance between the polymer and the lithium electrode. thereby resulting in the increased conductivity:

It was shown in 1984 that poly [bis(methosyethosyethoxy) phosphazene] (MEEP)/ithium salt electrolyte ș'stem exhibited higher conductivity $\left(1.7 \times 10^{-5} \mathrm{~S} \mathrm{~cm}^{-1}\right.$ at room temperature) than that of PEO-lithium salt electrolyte system. ${ }^{-8}$ The conductivity of the poly [bis(methoxyethoxyethoxy)phosphazene] (MEEP)/lithium salt electrolyte system further increased to about by five times by incorporating $2.5 \mathrm{wt} \% \mathrm{a}-\mathrm{Al}_{2} \mathrm{O}_{3}=9$ Similar to the case of PEO-based composite electrolyte, the conductivity enhancement was explained in terns of Lewis acid-base interaction between the filler. polymer. and salt. Other polymer-salt complex sy stems comprising either nanosized $\mathrm{Al}_{2} \mathrm{O}_{3}$ or nanosized $\mathrm{ZnO}$ filler. such as $\mathrm{PAN}_{-} \mathrm{LiClO}_{4}-$ 
$\mathrm{Al}_{-} \mathrm{O}_{3}{ }^{30}{ }^{31} \mathrm{PEG}-\mathrm{LiClO}_{4}-\mathrm{Al}_{2} \mathrm{O}_{3}{ }^{31}$ (UV-cured cyclic phosphazene)- $\mathrm{LiClO}_{4}-\mathrm{Al}_{2} \mathrm{O}_{3}{ }^{32}$ and $\mathrm{PEO}-\mathrm{LiClO}{ }_{4}$-(organic acid) $-\mathrm{Al}_{2} \mathrm{O}_{3}$. $\mathrm{PEO}-\mathrm{LiN}\left(\mathrm{SO}_{2} \mathrm{CF}_{3}\right)_{2}-\mathrm{ZnO}^{3+}$ were also investigated. The ionic conductivity and the lithium ion transference numbers of a conventional SPE. PEO-LiX was considerably increased by the addition of a ceramic oxide filler (about $2.5-15 \mathrm{wt} \%$ ). Even though the incorporation of a nanosized ceramic filler was able to increase the conductivity of PEO-LiX up to more than $10^{3}$ times, this conductivity value is still far from the desired for the practical application. ${ }^{29}$

Treated $\mathrm{SiO}_{2}$. Silica, a well-known material as a heterogeneous catalyst support. has also been expected to enhance the ionic conductivity of polymer electrolytes because the surface hydroxyl groups can be easily modified for a specific need.

It was reported that the conductivity of SPE comprising treated $\mathrm{SiO}_{2}$ as a filler was much higher than that containing untreated $\mathrm{SiO}_{-}{ }^{35.36}$ Capiglia $e t$ al. were able to improve the conductivity of $\mathrm{PEO}_{4} \mathrm{LiClO}_{4}$ by incorporating $\mathrm{SiO}_{2}$ particles. which was treated at $900{ }^{\circ} \mathrm{C}$ to remove surface hydroxyl groups on $\mathrm{SiO}_{2}{ }^{37}$ Contrary to this, hydrophilic silica was also found to enhance the stability of lithium metal/polymer electrolyte interface. ${ }^{38}$ A nanocomposite sy stem, PUA (polyurethane acrylate)- $\mathrm{LiN}\left(\mathrm{SO}_{2} \mathrm{CF}_{3}\right)_{2}$ containing $20 \mathrm{wt} \%$ hydrophilic silica. resulted in an improved performance of lithium battery cell at moderate temperature. suggesting that the addition of nano- $\mathrm{SiO}_{2}$ powders is capable of greatly improving the interfacial stability between the $\mathrm{Li}$ anode and the electrolyte. ${ }^{3.9}$

From these results, it is likely that the performance of the SPEs can be improved by incorporating either the thermally treated silica or untreated functionalized $\mathrm{SiO}_{2}$. Liu et al ${ }^{\text {ic }}$ found that surface-functionalized $\mathrm{SiO}_{2}$ by 2 -[methoxy (polyethy lenoxy)-propy'l] trimethoxy'silane could be better dispersed into the PEO matrix than untreated $\mathrm{SiO}_{2}$. The presence of polymeric moieties on the $\mathrm{SiO}_{2}$ surface was proven to improve the $\mathrm{Li}^{-}$-polymer interfacial stability. In a routine of immobilizing short-chained poly mer plasticizers onto the silica fillers in GPEs. ${ }^{3.41}$ poly (ethylene) glycol was grafted onto pristine $\mathrm{SiO}_{2}$ nanoparticle surface using toluene 2.4-diisocyanate as a bridging molecule. ${ }^{42}$ The fillers were then employed in a PEO$\mathrm{LiBF}_{4}$ system to obtain all-solid-state electrolytes. However. Lewis acid-base interactions between the polymer backbone and the fillers were weaker, leading to a decrease in $\mathrm{Li}^{+}$transference number. This can be attributed to the smaller number of $\mathrm{OH}$ groups on the silica surface compared with that on the unmodified silica.

The room temperature ionic conductivity of $\mathrm{PEO}-\mathrm{LiOCl}_{4}$ increased by more than two times when a functionalized $\mathrm{SiO}_{2}$ (Degussa-Huls. R805, 12 nm) possessing two surface silanol $(\mathrm{Si}-\mathrm{OH})$ groups and an octyl $\left(\mathrm{Si}^{-} \mathrm{C}_{8} \mathrm{H}_{1}\right)$ group was used as a filler after thermal treatment. Interestingly. thermal-induced segregation of silica particles was not observed and this could be responsible for the enhancement of conductivity. ${ }^{43}$ In another paper. the addition of commercially available mesoporous SBA-15 as fillers into a PEO-LiClO ${ }_{4}$-based SPE was found to improve the mechanical. electrochemical, and physicochemical properties of the electrolyte. ${ }^{44}$
In sunmary. silicone-based fillers enhanced the mechanical strength. conductivity. and electrochemical properties of the SPEs. especially by stabilizing the interfacial interaction between the electrolyte and the electrodes. Moreover. functionalized silicone-based fillers could be dispersed homogeneously in the electrolyte systems. Unfortunately. despite their high designability, silicone-based filler-containing SPEs exhibit insufficient conductivity and $\mathrm{Li}^{+}$transport at room temperature for practical application. Nonetheless, the cell performance with these electrolyte sy'stems was found stable up to thousands of stable cycles at $60^{\circ} \mathrm{C} .{ }^{39}$

Molecular sieves and zeolites. Molecular sieves. microporous materials with high BET surface areas and two-dimensional intersection channels. especially aluminosilicate molecular sieves (zeolites), have been evaluated as fillers for CPEs. Compared with those of traditional nanofillers, certain types of molecular sieves were shown to possess much stronger Lewis acid centers in their frameworks and inside the channels. which might contribute to the prevention of the crystallization tendency of the polymer host more effectively, thus resulting in a ligher degree of conductivity and $\mathrm{Li}^{-}$transference number enhancement. ${ }^{+5-18}$ The addition of a molecular sieve was found to decrease the crystallinity of PEO as well as increasing the amount of $\mathrm{PEO}$ sphenulites. thus resulting in a significantly enlanced ionic conductivity and electrochemical stability up to $4.5 \mathrm{~V}$. Remarkably: in comparative studies. zeolite fillers like ZSM-5 appeared to a better choice than the ceramic fillers. solid super acid. layered materials. and mesoporous materials. ${ }^{49.5 i}$

In a study by Xi et al., several ordered mesoporous silica (OMS) fillers were synthesized, characterized. and applied for $\mathrm{PEO}$ - $\mathrm{LiClO}_{4}$-based nanocomposite poly mer electrolytes. ${ }^{\text {if }}$ As reported. because of their mesoporous channels, OMS was capable of functioning as plysical cross-linking centers for the polymer chains. thus strengthening the mechanical stability of the system. In addition the conductivity. $\mathrm{Li}^{+}$transference number, electrochemical stability of the PEO-LiClO ${ }_{4}$-based electrolytes were significantly improved by the addition of OMS fillers. Further improvement in electrochemical properties of these electrolyte systems was also observed when OMS was modified using ionic liquids. ${ }^{5}$ Room temperature conductivities of $10^{-5} \mathrm{~S} \mathrm{~cm}^{-1}$ and $\mathrm{Li}^{-}$transference numbers of $0.3-0.5$ were achieved with PEO-based electroly tes containing $10 \cdot 15 \mathrm{wt} \%$ of molecular sieve or zeolite. Obviously, these values are encouraging, but still far from those required for practical lithium batteries.

Rare-earth oxide ceramics. Solid-state synthesis: inorganic ingredients are mixed and thermally calcinated at high temperature to form ceramic fillers directly. Subsequently. the solids are grinded to a specified grain size. Using this technique. D. Shanmukaraj et al prepared nanosized $\mathrm{SrBi}_{4} \mathrm{Ti}_{4} \mathrm{O}_{15}$ ferroelectric filler and applied for the PEG-LiClO temperature conductivity of $0.64 \times 10^{-9} \mathrm{~S} \mathrm{~cm}^{-1}$ was achieved at the concentration of $12.5 \mathrm{wt} . \% \mathrm{SrBi}_{4} \mathrm{Ti}_{4} \mathrm{O}_{15} .{ }^{5.3}$

Indirect synthesis: a homogeneous gel is prepared first. then dried. and heated to form foany flakes, which give very fine powder consisting of small sized particles after grinding. In the last step. the powder is decomposed at a very higher 
temperature to obtain electrolyte fillers. CPE containing 10 wt. \% nanosized $\mathrm{SrBi}_{4} \mathrm{Ti}_{4} \mathrm{O}_{1}$ ferroelectric fillers prepared by an indirect synthesis. showed a maximum conductivity of $0.75 \times 10^{.6} \mathrm{~S} \mathrm{~cm}^{-1}$ at room temperature, which is about 10 times higher than that with $\mathrm{SrBi}_{4} \mathrm{Ti}_{4} \mathrm{O}_{15}$ prepared from a direct synthesis. ${ }^{54}$

Through a combination of the above two methods. La .55 $\mathrm{Li}_{1035} \mathrm{TiO}_{3}$ fibers and mats were fabricated, then dispersed (20 wt.\%) into $\mathrm{PEO}-\mathrm{LiN}\left(\mathrm{SO}_{2} \mathrm{CF}_{2} \mathrm{CF}_{3}\right)=$ mixture containing 12.5 wt. $\% \mathrm{Li}^{-}$in PEO. ${ }^{55}$ Surprisingly these nanocomposite electrolytes showed a maximum ionic conductivity of $5.0 \times 10^{-4} \mathrm{~S}$ $\mathrm{cm}^{-1}$ at room temperature and $\mathrm{Li}^{-}$transference number of 0.7 . which are far above those of previously mentioned filler-containing electrolytes. Moreover. the interfacial stability of the electrolytes in contact with lithium-ion and lithium-metal anodes was further improved when the ceramic fibers were coated by PEO. Although the above SPEs systems exhibit sufficiently high room temperature conductivity for lithium batteries. no cell test result was reported in the study.

Solid super acid Sulfated metal oxide ceramics, solid super acids, including $\mathrm{SO}_{4}{ }^{3} / \mathrm{ZrO}_{-}, \mathrm{SO}_{4}{ }^{3-} / \mathrm{Fe}_{2} \mathrm{O}_{3}$, and $\mathrm{SO}_{4}{ }^{3-} / \mathrm{TiO}_{-}$, are being used as catalysts for a variety of chemical reactions. As the solid super acids possess strong acidic centers to interact with the oxygen atoms of PEO they can also find application as fillers for CPEs. ${ }^{59}$

In an early study ${ }^{\circ}$ nanosized $\mathrm{SO}_{4}{ }^{3} / \mathrm{ZrO}_{2}$ was reported to effectively reduce the crystallinity of $\mathrm{PEO}$ in $\mathrm{PEO}_{12}-\mathrm{LiClO}_{4}$. $\mathrm{SO}_{4}{ }^{-} / \mathrm{ZrO}_{2}$ system, thus resulting in enhanced ionic conductivity and $\mathrm{Li}^{-}$transference number. The decomposition voltage of the system increased by about $0.1-0.2 \mathrm{~V}$ compared with that of $\mathrm{PEO}_{12}-\mathrm{LiClO}_{4}$. The highest room temperature ionic conductivity of $2.1 \times 10^{-5} \mathrm{~S} \mathrm{~cm}^{-1}$ was attained with $7 \mathrm{wt} \%$ of $\mathrm{SO}_{4}{ }^{2} / \mathrm{ZrO}_{2}$.

Using a $\mathrm{PEO}-\mathrm{LiBF}_{+}$-sulfated-ZrO_ electroly te ș'stem. Croce et al. achieved a surprisingly high $\mathrm{Li}^{+}$transference number of 0.8 . which is about two times higher than that obtained with ceramic-free electrolyte, and they also expected that a value approaching unity could finally be obtained soon. ${ }^{61.62}$

Femoelectric materials. Despite the high density of functional groups. PEOs have relatively low dielectric constant $(\varepsilon=$ 5). and thus the dissociation of an electrolyte salt is limited. ${ }^{\text {t3 }}$ For this reason, electroceramic fillers are introduced into the polymer electrolyte matrixes to increase the polarity of the polymer backbone and to increase the charge separation and conductivity. The addition of a small amount of ferroelectric $\mathrm{BaTiO}_{3}(1.4 \mathrm{wt} \%$ ). a widely used capacitor material with high dielectric constant $\left(10^{3}-10^{5}\right)$, was found to enhance the lithium interface stability and the conductivity of $\mathrm{PEO}-\mathrm{LiClO}_{+} \mathrm{SPE}$. especially at temperatures higher than $70^{\circ} \mathrm{C}{ }^{64}$

A PEO-based polymer electrolyte system employing LiN $\left(\mathrm{SO}_{2} \mathrm{C}_{2} \mathrm{~F}_{5}\right)_{2}$ as an electrolyte and $\mathrm{BaTiO}_{3}(10 \mathrm{wt} \%)$ as the ferroelectric filler showed excelent cell performance without a significant loss of initial capacity upon charging to $3.9 \mathrm{~V}$ at $80^{\circ} \mathrm{C} .^{65}$ In the extent study, it was also reported that solid-PEO solution of a salt mixture of $\operatorname{LiPF}_{6}(1 \mathrm{wt} \%)$ and $\mathrm{LiN}\left(\mathrm{SO}_{2} \mathrm{C}_{2}\right.$ $\left.\mathrm{F}_{5}\right)_{2}\left(9 \mathrm{nt} \%\right.$ ) with dispersed $\mathrm{BaTiO}_{3}$ fillers exhibited enhanced cell performance upon charging at $4.2 \mathrm{~V}^{66}$ Similar results of the studies with $\mathrm{BaTiO}_{3}$ fillers were also obtained using the
$\mathrm{LiN}\left(\mathrm{SO}_{2} \mathrm{C}_{2} \mathrm{~F}_{5}\right)_{2}-\mathrm{PEO}$-based polymer electrolyte. ${ }^{67}$

However. it seems that much work needs to be done to improve the conductivity at room temperature for both solid super acid-containing and electroferric material-containing SPEs to be used as lithium battery electrolytes for practical purposes.

Carbon. Carbon is an important anode material in Li-ion batteries. In an early study of PEO-based composite cathodes. Appetecchi et al. recognized that the addition of a small volume fraction $(<1.5 \%$ ) of carbon with moderately high surface area $\left(\sim 60 \mathrm{~m}^{2} \mathrm{~g}^{-1}\right)$ led to excellent performance of composite lithium polymer electrolytes in terms of conductivity and interfacial stability. ${ }^{68}$ Although the mechanism of the conductivity enhancement in the composite electrolyte is still unclear the room temperature ionic conductivity of $2.0 \times$ $10^{-4} \mathrm{~S} \mathrm{~cm}^{-1}$ reported for SPEs is really pronusing and meaningful with the addition of such an inexpensive material.

\section{Cellulose Nanocrystals}

Nanocomposite polymer electrolytes based on poly(oxyethy lene) and cellulose nanocrystals were studied by Samir $e t$ $a l^{6,2 i 1)}$ The addition of $6-10$ wt. \% of nanocrystalline cellulose filler (whiskers) to a $\mathrm{PEO}-\mathrm{LiN}\left(\mathrm{SO}_{2} \mathrm{CF}_{3}\right)_{2}$ polỳmer sy stem reinforced the mechanical properties of the system without affecting the lithium transference number. However the ionic conductivity was not improved by the addition of the fillers. In contrast. it is also adnitted that the hydroxyl groups of the cellulose fillers led to the electrolyte instability in contact with lithium electrodes

\section{Active Fillers for Lithium Batteries' CPEs}

Although the addition of nonconducting fillers into the polymer matrix significantly inproves the electrochemical properties of the electrolytes. the room temperature conductivity is still too low (mostly less than $10^{-4} \mathrm{~S} \mathrm{~cm}^{.1}$ ) to be used in the practical applications. As an alternative active fillers with very high lithium-ion conductivity were extensively explored.

The first study on the active filler was reported by \$kaanup et al., who investigated a CPE system. $\mathrm{PEO}-\mathrm{LiCF}_{3} \mathrm{SO}_{5}$ containing $\mathrm{Li}_{3} \mathrm{~N}$. $^{7]}$ It was reported that the incorporation of small amounts of $\mathrm{Li}_{2} \mathrm{~N}$. increased the room tenperature conductivity of $\mathrm{PEO}-\mathrm{LiCF}_{3} \mathrm{SO}_{3}$ up to 1,000 times. Other early studies carried out with a filler having composition of $0.56 \mathrm{Li}_{2} \mathrm{~S}$ $0.19 \mathrm{~B}_{2} \mathrm{~S}_{3} 0.25 \mathrm{LiI}$ and $\mathrm{Li}_{3} \mathrm{~N}$, achieved the conductivities of $3 \times$ $10^{-4}$ and $1.4 \times 10^{-4} \mathrm{~S} \mathrm{~cm}^{-1}$, respectively ${ }^{3}$ However both of these active fillers are highly unstable and sensitive in terms of heat and environment. More disappointingly, $\mathrm{Li}_{\S} \mathrm{N}$ even has a poor electrochemical stability ( $2.5 \mathrm{~V}$ versus $\left.\mathrm{Li}^{-} / \mathrm{Li}\right)$.

Among the active fillers of ceranic type, $\gamma-\mathrm{LiAlO}_{2}$ was most intensively investigated because $\gamma-\mathrm{LiAlO}_{2}$ has larger defect-rich grain boundaries than inert ceramics, which might contribute to the ionic conduction. ${ }^{4 A}$ Especially the interface of $\mathrm{Li} /(\mathrm{PEO})_{8}-\mathrm{LiClO}_{4}-\gamma-\mathrm{LiAlO}_{2}$ showed the niost stable electrochenical behavior. compared with the interface of $\mathrm{Li}$ / $(\mathrm{PEO})_{3}-\mathrm{LiClO}_{4}$ and $\mathrm{Li} / \mathrm{PAN}-\mathrm{EC}-\mathrm{PC}-\mathrm{LiClO}_{4}$. 
$\mathrm{Li}^{-}$-conducting glass also attracted much interest in the last decade. Employing $\mathrm{Li}^{+}$-conducting glass. $1+\mathrm{Li}_{-} \mathrm{O}_{9} \mathrm{Al}_{2} \mathrm{O}_{3} 38$ $\mathrm{TiO}_{2} 39 \mathrm{P}_{2} \mathrm{O}_{\text {s. }}$. which was shown to have the highest solid-state $\mathrm{Li}^{-}$conductivity (around $10^{.3} \mathrm{~S} \mathrm{~cm}^{-1}$ ), ${ }^{76}$ Zhang et al. reported a PEO-LiN( $\left(\mathrm{SO}_{2} \mathrm{C}_{2} \mathrm{~F}_{5}\right)_{2}$-based electrolyte with a room temperature conductivity of $1.7 \times 10^{-4} \mathrm{~S} \mathrm{~cm}^{-1}$. an $\mathrm{Li}^{+}$transference number of 0.4 . and an electrochemical stability window to $+5.1 \mathrm{~V}$ versus $\mathrm{Li} / \mathrm{Li}^{+}$. In another report, the addition of a glass powder of $0.4 \mathrm{~B}_{2} \mathrm{~S}_{3} .0 .4 \mathrm{Li}_{2} \mathrm{O} .0 .2 \mathrm{LiSO}_{4}$ was found to suppress the charge resistance of $\mathrm{Li} / \mathrm{PEO}-\mathrm{LiBF}_{4}$ interface by a factor of three. ${ }^{78}$ Impressively, a $\mathrm{Li}^{-}$transport number of 0.98 for a glass-polymer composite electrolyte containing $13 \mathrm{vol} . \%$ $\mathrm{PEO}-\mathrm{LiN}\left(\mathrm{CF}_{3} \mathrm{SO}_{2}\right)_{2}$ and $87 \mathrm{vol} . \% 0.56 \mathrm{Li}_{2} \mathrm{~S} .0 .19 \mathrm{~B}_{2} \mathrm{~S}_{3} .0 .25 \mathrm{LiI}$ was reported by Cho et al. ${ }^{\text {i9 }}$

In spite of these promising results. active fillers have not been successfully employed as all-solid-state electroly te system for practical lithium battery. mostly because of the insufficient conductivity at room temperature. In some case, the reported electrolyte containing active fillers had even much lower ionic conductivity at room temperature than that of inactive filler-containing systems.

\section{From Nanocomposite to Nanogel Composite Electrolytes}

To enhance the conductivity of CPEs, the addition of liquid electrolytes was suggested in an expectation to combine the advantages of both gel and nanocomposite polymer electrolytes. ${ }^{81.83}$ Nanogel composite electrolytes can be obtained either from a nanocomposite polymer electrolyte by incorporating a conventional liquid electrolyte (nanogel porous polymer electrolyte) into a porous stricture of a nanocomposite polymer or from a GPE containing dispersed nanoparticles (homogeneous nanogel polymer electrolyte). As a whole the addition of filler particles into the GPE increases the ionic conductivity. porosity, and liquid uptake, while reducing the risk of liquid leakage.

Rutile $\mathrm{TiO}_{2}$ nanoparticles were claimed to be more easily dispersed in the polymer solution than the anatase type. These materials were used as nanofillers for a PVdF-HFP-based nanocomposite porous polymer electrolyte swollen with $1 \mathrm{M}$ $\mathrm{LiPF}_{6}$ in EC:DMC $(1: 1 \mathrm{v} / \mathrm{v}){ }^{8+-85}$ The electrolyte system was reported to possess low liquid uptake and sufficient ionic conductivity. Such a high ionic conductivity was explained by the liquid medium within nanopores as well as effective ion transport supported by $\mathrm{TiO}_{2}$ ninoparticles. Excellent electrochemical stability of the polymer electrolyte was also observed. and $30-40 \mathrm{wt} . \% \mathrm{TiO}_{2}$ was suggested as the optimum. Similar results were also reported with the electrolyte sy stems based on PVdF-HFP and a filler like $\mathrm{TiO}_{2}$. nanosized $\mathrm{Al}(\mathrm{OH})_{\mathrm{l}}$, molecular sieves. or zeolites. ${ }^{86.95}$

Wu $e t$ al carried out a comparative study with metal oxides and mesoporous zeolites as fillers. which were dispersed in the porous polymer matrix of PVdF-HFP-based electrolyte comprising EC:PC $(1: 1 \mathrm{v} / \mathrm{v})$ mixture as the liquid plasticizer. ${ }^{96}$ The addition of these solid fillers into the filler-free electrolytes increased the ionic conductivity twice. from $1.2 \times 10^{-3}$ $\mathrm{S} \mathrm{cm}^{-1}$ to $2.1 \times 10^{-3} \mathrm{~S} \mathrm{~cm}^{-1}$. possibly because of the increased porosity and liquid uptake. More advantageously. these electrolyte systems showed the electrochenical stability up to $5.5 \mathrm{~V}$ (versus $\mathrm{Li} / \mathrm{Li}^{-}$).

$\mathrm{SiO}_{2}$-containing poly'(ethylene glycol) diacrylate (PEGDA)based nanogel electrolytes were prepared with $1 \mathrm{M} \mathrm{LiPF}_{6}$ in EC:DMC:DEC (1:1:1 by volume) solution as the liquid plasticizer ${ }^{97}$ Cyclic voltammograms of the system were reported up to $5 \mathrm{~V}$. and the superior chemical stability was ascribed to the addition of $\mathrm{SiO}_{2}$. The nanosized $\mathrm{SiO}_{2}$ was found to contribute to the rapid formation of conpact and stable passive films. which stabilize the interface between the electrolyte and lithium electrode. With all liquid contents, the nanogel system exhibited a little higher conductivity than that of the corresponding GPE. A cell performance enploying the above electrolyte system retained $97 \%$ initial discharge capacity after 30 cycles at $0.2 \mathrm{C}$ rate. which was more stable than that of PEGDA-based GPE developed by Song et al ${ }^{98}$

In terms of practical application. an impressive cell performance was reported by Yang et al. ${ }^{99}$ Nanogel polymer electrolytes of PVdF/PEGDA/PMMA containing $\mathrm{LiPF}_{\sigma}$ $\mathrm{LiCF}_{3} \mathrm{SO}_{3}(10 / 1$, wt.\%) were prepared enploying several traditional ceramic fillers such as $\mathrm{Al}_{2} \mathrm{O}_{3}$. $\mathrm{BaTiO}_{3}$, and $\mathrm{TiO}_{2}$. The cell performance of the system with $\mathrm{Al}_{2} \mathrm{O}_{2}$ filler maintained $95 \%$ of initial capacity after 100 cycles at $\mathrm{C} / 2$ rate.

\section{Conclusions}

In contrast to the ionic transport mechanism in SPEs and GPEs, in which the ion motion is coupled with the segmental relaxation of the polymer host. the ionic transport mechanism in CPEs can be explained as an indirect result of Lewis acid-base ty'pe interactions between the filler surface and the polymer host. Because of these interactions, the crystallinity can be reduced to a great extent, allowing $\mathrm{Li}^{+}$to move more freely' either on the interface between the low-density polymer phase and the particles or on the surface of the particles. The addition of these solid fillers to the polymer electrolyte significantly increases the properties of the electrolytes in terms of ionic conductivity, mechanical stability, thermal and chemical stability. and stability of the interface between the electrolytes and lithum electrodes.

Nanogel composite electrolytes have been recognized as innovative alternatives due to their excellent electrochemical and mechanical properties comprising advantages of both CPEs and GPEs.

The presence of nanoparticle fillers in the GPEs is found to improve the liquid uptake. leading to an increase in ionic conductivity and a decrease in liquid leakage. Remarkably, nanogel composite electrolytes show superior ionic conductivities and electrochemical stability:

In conclusion, nanocomposite and nanogel composite electrolytes can be regarded as the most promising next generation electrolytes with superior properties. such as higher safety. much longer cycle life. higher energy density. and shorter charging time.

Aclnowledgments. This work was support by an Institutional fund from the Korea Institute of Science and Technology 


\section{References}

1. Gray F. M. Sold Polmer Electrolvtes Fundamental and Technological Applications: VCH: London, New York, 1991.

2. Stephan, A. M.; Nahm, K. S. Polmer 2006, 47, 5952 .

3. Persi, L.: Croce, F.; Scrosati, B.: Plichta, E.; Hendrickson, M. A. J. Electrochen. Soc: 2002, 149, A2 12

4. Appetecchi, G. B.: Croce, F.; Dautzenberg, G.; Mastragostino, M.: Ronci, F.: Scrosati, B.; Soavi, F.; Zaneli, A.; Alessandrini, F.; Prosini, P. P. J. Electrochent. Soc. 1998, 145,4126

5. Appetecchi, G. B.; Romagnoli, P; Scrosati, B. Electrochent. Common. 2001, 3, 281.

6. Murata, K.; Izuchi, S.; Yoshihisa, Y. Electrochintica Acta 2000, 45.1501

7. Li, Z. H.; Zhanga, H. P.: Zhanga, P.: Wua, Y. P; Zhou X. D. J. Power Sources 2008 . 184, 562

8. Raghavana, P.; Choi J.: Alu1, J.: Chanhana, G. C. G. S.: Alu1, H.; Nah. C. J. Power Sources 2008. 184, 437.

9. Gadjourova, Z: Andreev, Y. G.: Tunstall, D. P.; Bruce, P. G. Nature (London) 2001, 412,520 ).

10. Croce, F.; Curini, R.: Martinelli, A.; Persi, L.; Ronci, F.; Scrosati, B. Caminiti, R. T. Phws. Chem. B 1999, 103, 10632

11. Chung, S. H.; Wang, Y.; Persi, L.; Croce, F.; Greenbaum, S. G.; Scrosati, B.: Plichta, E. J. Power Somces 2001, 97/98, 644.

12. Croce, F.; Appetecchi, G. B.; Persi, L.; Scrosati, B. Vatme (London') 1998, 394, 456.

13. Tiang, G.; Maeda, S.; Yang, H.; Saito, Y; Tanase, S.; Sakai, T. $J$. Power Sonces 2005, $1+1,143$

14. Croce, F; Persi, L.; Ronci, F.; Scrosati, B. Solid State Iontics $2000,135,47$

15. Scrosati, B.: Croce, F; Panero, S. J. Power Sources 2001, 100 , 93.

16. Wang, G. X: Yang, L.; Wang, I. Z: Liu, H. K: Dou, S. X. J. Kanoscience and Nanotechologv 2005, 5, 1135

17. Rajendran, S.: Uma, T. Ionics 2000, 6, 288 .

18. D'Epifanio, A.: Semaino Fiory, F.; Licoccia, S.; Traversa, E.: Scrosati, B.: Croce. F. J Appl Electrochem. 2004.34, 403

19. Weston, T. E: Steele, C. H. Solid State lonics 1982, 7, 75.

20. Croce, F: Curini, R.; Martinelli, A.: Persi, L.: Ronci, F: Scrosati, B. Caminiti, R. J. Phys. Chem. B 1999, 103, 10632.

21. Kumar, B.; Scanlon, L. G. Solid State Ionics 1999, I2 + 239

22. Strauss, E.; Golodnitsky, D; Ardel, G.; Peled, E. Electrochim. Acta 1998, 43, 1315

23. Xie, J.; Dulan, R. G.; Han, Y.; Kerr, J. B. Solid State Lonics 2004 , 175,755

24. Lin, C. W; Hung, C. L.; Venkateswarlu, M.; Hwang, B. J. $J$. Power Sources 2005, 146, 397.

25. Dissanayake, M. A. K. L. Ionics 2004, 10, 221

26. Krawiec, W: Scanlon, L. G.: Fellner, T. P.; Vaia, R. A. Vasudevan, S.: Giannelis. E. P. J. Power Sources 1995, 54, 310.

27. Shin, T. H.: Kim, K. W; Aln, H. J.: Alu1, J. H. Mater: Sci. Eng. B 2002, B95, 148 .

28. Blonsky, P. M.; Shriver, D. F.: Austin, P.: Allcock, H. R. J. Am. Chem Soc: 1984, 106, 6854.

29. Chen-Yang, Y. W.; Chen, H. C.; Lin, F. T.; Liao, C. W: Chen, T. L. Solid State lonics 2003, 156, 383

30. Wang, Z: Huang, X.; Chen, L. Electrochent and Solid-State Lett. $2003,6, \mathrm{E} 40$.

31. Singh, Th. J; Bhat, S. V. J. Power Sonres 2004, 129, 280

32. Chen-Yang, Y. W: Chen, S. Y: Yuan, C. Y.; Tsai, C. H.; Yan, D. P. Aacromolecules 2005, 38, 2710 .

33. Park, I. W.: Jeong, E. D.: Won, M.: Shim, Y. J. Power Sources $2006,160,674$.

34. Xiong, H.; Wan1, Z.: Xie, D.; Cheng, L.; Xia, Y. J. Mater Chem. $2006,16,1345$.

35. Walls, H. I: Zhou, J.: Yerian, J. A.: Fedkiw, P. S.: Khan, S. A.: Stowe. M. K.: Baker, G. L. J. Power Sources 2000. 89. 156

36. Matsuo, Y.: Kuwano, J. Solid State Ionics 1995, 79, 295.
37. Capiglia, C.: Mustarelli, P.: Quartarone, E.; Tomasi, C.: Magistris, A. Solid State lonics 1999, 118,73

38. Lee, B.: Choi, N.; Park, J. Pohm. Bull 2002, 19.63.

39. Tiang, G.: Maeda, S.; Saito, Y; Tanase, S.: Sakai, T. J. Elecnochem. Soc. 2005. 152, A767.

40. Liu, Y.: Lee, J. Y.; Hong, L. J. Power Sonces 2002, 109, 507.

41. Lanter, U.: Meyer, W. H.: Wegner, G. Macromolecules 1997, 30 , 2092.

42. Zhang, S.; Lee, Tim Y.; Hong, L. J. Poner Sontes 2004, 134, 95

43. Ji, K.; Moon, H.; Kim, J.; Park, T. J. Power Solerces 2003, 117 , 124

44. Xi, J.; Qiu, X.; Ma, X.; Cui, M.; Yang, I.; Tang, X.; Zhu, W.; Chen, L. Solid State Ionics 2005, 176, 1249

45. Xi, T.; Bai, Y; Qiu, X; Zhu, W.; Chen, L.; Tang, X. New J. Chem. $2005,29,1454$

46. Xi, J; Tang, X. Electrochint Acta 2006, 51,4765.

47. Xi, J.: Qill, X.; Wang, J.: Bai, Y.: Zhu, W.: Chen, L. J. Power Sonces 2006. 158.627

48. Munichandraiah, N.: Scanlon, L. G.; Marsh, R. A.; Kumar, B.; Sircar, A. K. Proceedings-Electrochemical Socien 1993, $93,97$.

49. Xi, J: Miao, S.: Tang, X. Macromolecules 2004, 37, 8592.

50. Xi, I.: Ma. X.: Cui, M.: Huang, X.: Zheng. Z.: Tang, X. Chin. Sci. Bull. 2004, 19.785 .

51. Xi, I.: Qiu, X.: Zhu, W: Tang. X. M/icroporons Mesoporons Nater: 2006, 88,1

52. Tominaga, Y.; Asai, S.; Sumita, M.; Panero, S.; Scrosati, B. $J$. Power Soltres 2005, $146,402$.

53. Shanmukaraj, D.; Murugan, R. J. Power Soukes 2005, $149,90$.

54. Shanmukaraj, D.; Wang, G. X.; Liu, H. K.; Murugan, R. J. Electrochem. Soc. 2005, 152(1), A205.

56. Pietrogiacomi, D.; Campa, M. C.; Tuti, S.; Indovina, V. Appl. Catal $B 2003,+1,301$.

57. Yaday, G. D.: Sengupta, S. Ong. Process Res. Dev 2002. 6. 256

58. Mishra, H. M.; Parida, K. M. Appl. Catal .4 2002, 22t, 179

59. Xi, J.: Qiu, X.; Zheng, S.; Tang. X. Pohm. 2005, 46,5702

60. Xi, J.: Tang. X. Chem. Phys. Lett. 2004, 393, 271

61. Croce, F; Settimi, L.; Scrosati, B. Electrochem Commm. 2006, 8,364 .

62. Croce. F.: Sacchetti. S.: Scrosati. B. J. Power Sources 2006. 162. 685 .

63. Reiche, A.; Steurich, T.; Sandner, B.; Lobitz, P.; Fleischer, G. Electrochim. Acta 1995, to, 2153.

64. Sun, H. Y.; Soln, H.-J.; Yamamoto, O.; Takeda, Y. J. Electrocitent. Soc. $1999,146,1672$.

65. Li, Q.; Imanishi, N.; Takeda, Y.; Hirano, A.; Yamamoto, O. Ionics 2002, 8.79

66. Li, Q.; Imanishi, N.; Hirano, A.; Takeda, Y.; Yamamoto, O. $J$. Power Sources 2002, 110,38

67. Itoh. T: Ichikawa. Y: Uno, T:: Kubo, M.: Yamamoto, O. Solid State lonics 2003, 156, 393

68. Appetecchi, G. B.; Passerini, S. Electrochim .Acta 2000, 45 , 2139.

69. Azizi Samir, M. A. S.: Alloin, F.: Gorecki, W.: Sanchez, I.: Dufresne, A. J. Phes. Chem. B 2004, 108, 10845.

70. Azizi Samir, M. A. S.: Alloin, F.; Sanchez, T.-Y.; El Kissi, N.; Dufresne. A Macromolecules 2004, 37, 1386.

71. Skaarup, S.; West, K.; Zachaul-Christiansen B. Solid State Ionics $1988,28-30,975$

72. Appetecchi, G. B.; Passerini, S. Electrochim. Acta 2000, t5, 2139

73. Quataorone, E:; Mustarelli, P.; Magistris, A. Solid State Ionics $1998,110,1$

74. Capuano, F.; Croce, F.; Scrosati, B. J. Electrochem. Soc. 1991, $138,1918$.

75. Croce, F; Scroseti, B. J. Power Sonrees 1993, 43144, 9.

76. Fu, J. J. Mater: Sci. 1998, 33, 1549.

77. Zhang, X.; Wang, C.: Appleby, A. I.: Little, F. E. J. Power Sonces 2002, 112, 209 . 
78. Kunnar, B.: Schaffer, J. S.; Munichandraiah, N.; Scan1lon, L. G.J. Power Sources 1994, 47,63 .

79. Cho, J.: Liu, M. Electrochem. Acta 1997, 12, 1481

80. Wang, Y.; Pan Y:; Kim, D. J. Power Sonres 2006, 159,690.

81. Tacob, M. M. E.: Hackett, E: Giannelis, E. P. J. Mater: Chem. $2003,13,1$

82. Wachtler. M: Ostrovskii, D. Tacobsson, P.: Scrosati, B. Electrochim. Acta 2004, 50, 357 .

83. Slane, S.: Salomon, M. J. Power Sotrces 1995, 55, 7

84. Kin, K. M.: Ko, J. M.: Park, N.; Ryu, K. S.: Chang, S. H. Solid State lonics 2003, 161, 121

85. Kim, K. M.; Kim, J.; Rvu, K. S. Afacromol. Mater: Eng. 2006, 291,1495 .

86. Jiang, Y; Chen, Z; Zhuang, Q; Xu, T,; Dong, Q; Huang, L.: Sun. S. J. Power Sources 2006, 160, 1320.

87. Stephan, A. M.; Nahm, K.; Kulandainathan, M. A.; Ravi, G.: Wilson, I. J. Appl. Electrochent. 2006, 36, 1091.

88. Wu, C.: Lu, M.; Tsai, C.; Chuang, H. J. Power Sources 2006, 159.295
89. Kim, K. M.; Park, N.; Ryu, Kwang S.: Chang, S. H. J. Appl. Polmm. Sci. 2006, 102, 140.

90. Kim, K. M.: Park, N.: Ryul, K. S.: Chang, S. H. Electrochim . Acta $2006,51,5636$

91. Teon, T.; Kim, M.; Kwak, S. J. Power Sources 2006, 162, 1304.

92. Aravindan, V: Vickraman, P. Ionics 2007, 13, 277.

93. Aravindan, V; Vickraman, P. Solid Stote Sci. 2007, 9, 1069.

94. Jiang, Y.; Chen, Z.; Zhuang, Q.; Xu, J.; Dong, Q.; Huang, L.; Sun, S. J. Power Sources 2006, 160,1320 .

95. Xi, J.: Qiu, X.; Chen, L. Solid State lonics 2006, 177, 709

96. Wu, C.: Lu, M.: Tsai, C.; Chuang, H. J. Power Sources 2006. 159.295 .

97. Qiu, W.; Ma, X.; Yang, Q; Fu, Y.; Zong, X. J. Power Sources $\mathbf{2 0 0 4}, 138,245$

98. Song, M. K.; Cho, J. Y.; Cho, B. W; Rhee, H. W. J. Power Soures 2002, 110, 209.

99. Yang, C.: Kim, H.: Ná, B.: Kum, K.: Cho, B. W. J. Power Sonces 2006, 156,574 